\title{
Determination of Inorganic Selenium Species in Dietary Supplements by Hyphenated Analytical System HPLC-HG-AAS
}

\author{
L. Kozak • M. Rudnicka • P. Niedzielski
}

Received: 11 December 2011 / Accepted: 4 January 2012 / Published online: 18 January 2012

(C) The Author(s) 2012. This article is published with open access at Springerlink.com

\begin{abstract}
Construction and optimisation of a hyphenated analytical system for high performance liquid chromatography with hydride generation atomic absorption spectrometry detection system are described together with results of its use for investigation of food products. The use of anionexchange chromatographic column permitted separation of inorganic selenium species $\mathrm{Se}(\mathrm{IV})$ and $\mathrm{Se}(\mathrm{VI})$ at the limit of detection of $10 \mathrm{ng} \mathrm{mL} \mathrm{m}^{-1}$ for both species. The analytical system was used for determination of selenium species in dietary supplements available on the Polish market. The content of inorganic selenium species was found not to exceed $50 \%$ of its total content, and in the majority of products, the dominant species was Se(IV). In the majority of products, the total contents of selenium were close to those declared by the producers.
\end{abstract}

Keywords Dietary supplements · Selenium · Speciation · Hyphenated techniques

\section{Introduction}

According to the Polish law, the dietary supplements are not medical therapy drugs. Although they are available mostly in the chemists', they are not subjected to such a strict control as pharmaceutical products. They cannot include substances harmful for human health but their potential beneficial effect does not have to be documented. The

L. Kozak $\cdot$ M. Rudnicka $\cdot$ P. Niedzielski $(\bowtie)$

Faculty of Chemistry, Department of Water and Soil Analysis,

Adam Mickiewicz University,

24 Drzymały Street,

60-613 Poznań, Poland

e-mail: pnied@amu.edu.pl consumer knowledge of the contents of dietary supplements is based on declarations of the producers. Selenium in animal tissues is mainly present in the form of selenomethionine or selenocysteine. In dietary supplements, most often selenomethionine is used as it is not synthesised in human organism. Over $90 \%$ of this compound is absorbed by the same mechanism as methionine itself (Institute of Medicine 1997). As for the reasons for diet supplementation in selenium, it should be mentioned that the intake of selenium above the recommended level can be a protection against neoplasmic diseases. Selenium is engaged in a number of functions, it is an antioxidant, it is involved in the metabolism of thyroid hormones, in redox reactions and in functioning of the immune system. Many diseases such as cancer, circulatory system diseases, asthma and others have been related to a low level of selenium (Thomson 2004). According to the epidemiological data, elevated levels of antioxidants can protect against chronic diseases so a proper level of antioxidants (ascorbic acid, alpha-tocopherol, betacarotene, selenium and coenzyme Q10) can be a factor preventing many diseases. The use of vitamin supplements has been proved to be related to a lower risk of cardiovascular diseases (Wolters et al. 2006). Supplementing dietary with selenium also seems beneficial in animals. The experimental study that lasted for 504 days, in which sheep and lambs were administered dietary supplement with sodium selenate, has shown that this element can be used as a component of sheep diet to a higher degree than hitherto believed and its maximum level in the organism can reach $2 \mathrm{mg} / \mathrm{kg}$ body weight (Davis et al. 2005). Stomach and intestine dysfunctions reduce the absorption of selenium leading to its deficiency. The natural sources of selenium are: beer yeast, wheat germs, butter, garlic, sunflower seeds, Brazilian nuts, raisins, liver, kidneys, freshwater and sea fish. 


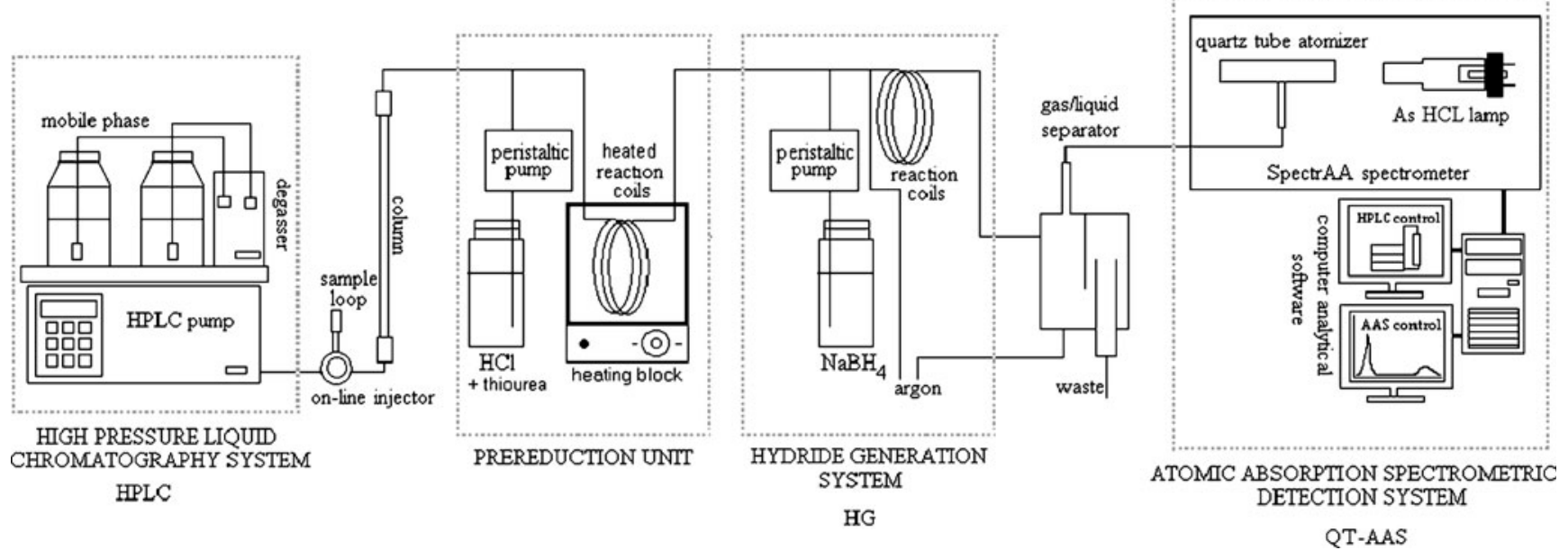

Fig. 1 Component diagram of the elaborated HPLC-HG-AAS system (follow (Niedzielski 2005), changed)

The subjects of concern of speciation studies have been mainly organic selenium species because of their physiological significance (Guerin et al. 1999). In the hyphenated systems, detection has been performed mainly by the spectrometric methods from among which the ICPMS systems were most often used (Hill et al. 2003; Pedersen and Larsen 1997; Łobiński and Szpunar 1999). Determination of inorganic selenium species can be also performed with detection performed by AFS or AAS systems in combination with hydride generation after preliminary on-line reduction of the $\mathrm{Se}(\mathrm{VI})$ species (Wallschlaeger and Bloom 2001; Bermejo et al. 2001). Moreover, on-line mineralisation of organoselenium compounds permits determination of organic species of selenium also in HGAAS systems (Marchante-Gayón et al. 1996).

In this study, determinations of inorganic species of selenium (Se(IV) and $\mathrm{Se}(\mathrm{VI})$ ) were carried out for selenium containing dietary supplements available in Poland. The determinations were performed using the hyphenated HPLCHG-AAS system newly arranged and optimised.

\section{Experimental}

\section{Instrumentation}

The hyphenated high performance liquid chromatography with hydride generation atomic absorption spectrometry

Table 1 Optimized analytical system conditions

\begin{tabular}{ll}
\hline Mobile phase & Phosphate buffer $3 \mathrm{~mL} \mathrm{~min}^{-1}$ \\
\hline Analytical column & Supelco LC-SAX 1; sample loop $200 \mu \mathrm{L}$ \\
Prereduction & $0.5 \mathrm{~mol} \mathrm{~L}-1$ thiourea in $10 \mathrm{~mol} \mathrm{~L}^{-1} \mathrm{HCl}$ \\
& $100 \mathrm{~cm}$ loop; temperature $100{ }^{\circ} \mathrm{C}$ \\
Hydride generation & $3 \% \mathrm{NaBH} 4$ in $1 \% \mathrm{NaOH}$ \\
AAS detection & Atomization $900{ }^{\circ} \mathrm{C}$; Selenium HCL lamp \\
& $196.0 \mathrm{~nm}$; current $10 \mathrm{~mA}$; slit $0.5 \mathrm{~nm}$ \\
\hline
\end{tabular}

detection (HPLC-HG-AAS) system has been constructed in previous work (Niedzielski 2005) and is shown in Fig. 1.

The HPLC system consisted of a Shimadzu liquid chromatograph (LC-10A) equipped with a HPLC pump (LC10AT), vacuum degasser unit (GT-104) and anion-exchange column Supelco LC-SAX1 $(250 \mathrm{~mm}, 4.6 \mathrm{~mm}$ i.d., resin particle size $5 \mu \mathrm{m}$ ) thermostatted by column oven (CTO10ASvp). The chromatographic run was isocratic at $3 \mathrm{~mL} \mathrm{m^{-1 }}$ with an injection volume of $200 \mu \mathrm{L}$. PEEK transfer tubing of the eluent from the LC column to the hydride generation unit was inserted into a Tygon sleeve. The continuous hydride generation system (VGA-77, Varian) consisted of a manually controlled, four channel peristaltic pump with Tygon tubing $(0.6 \mathrm{~mm}$ i.d.), one reaction coil (PTFE tubing $0.8 \mathrm{~mm}$ i.d., $75 \mathrm{~cm}$ length) and three-way connectors. The gas-liquid separator was made from glass and the interior dead volume was $3 \mathrm{~mL}$. All measurements were performed with a Model SpectraAA 220FS spectrometer (Varian, Australia). For the atomization of the selenium hydrides (detected at $196.0 \mathrm{~nm}$ ), a heating controller, electrothermally heating mantle and a quartz tube

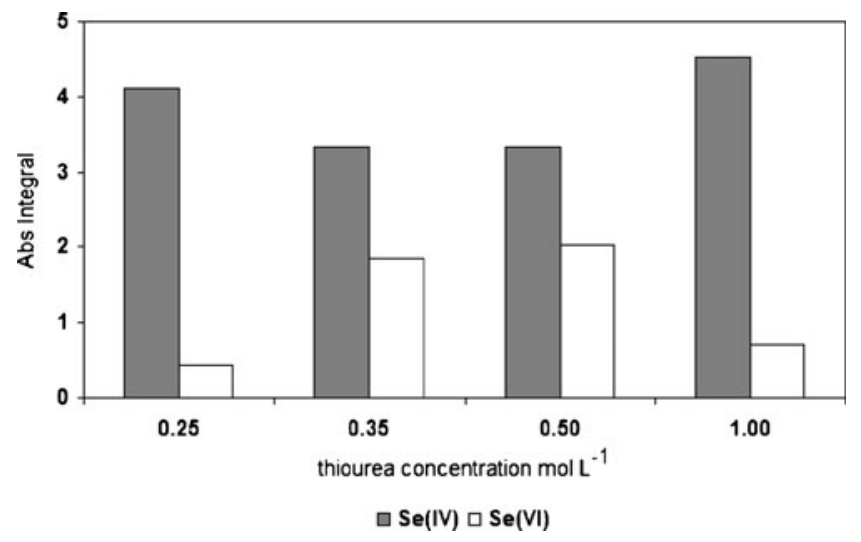

Fig. 2 Prereduction with different thiourea concentration in $10 \mathrm{~mol} \mathrm{~L}^{-1}$ $\mathrm{HCl}$ 


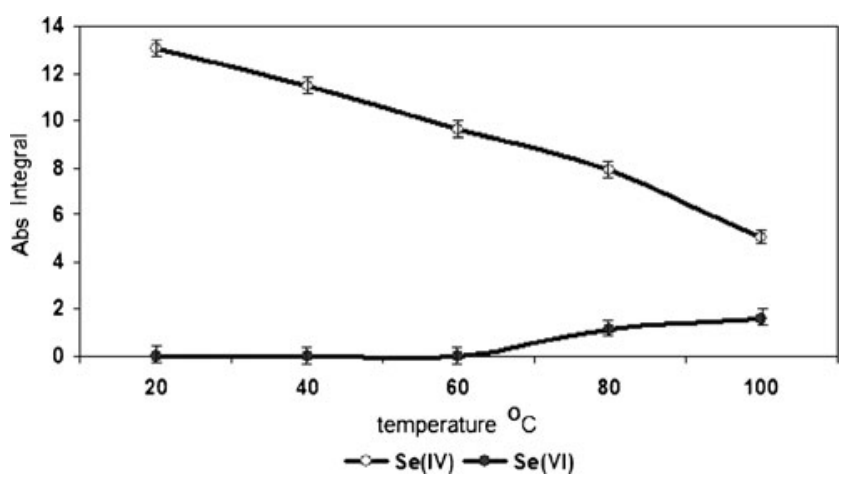

Fig. 3 Influence of prereduction temperature on analytical signal

(ETC-60, Varian) heated to $900{ }^{\circ} \mathrm{C}$ were used. The chromatograms were displayed on the screen of a personal computer by using the signal graphics option of the AAS software (Varian), and as a separate print out of the screen. Peak areas or height were calculated by the AAS software. The instrumental operating conditions for the HPLC and HG-AAS are listed in Table 1.

\section{Reagents}

Compressed argon gas of N-50 purity (99.999\%) obtained from BOC GAZY (Poland) was employed as the carrier gas for selenium vapour to the quartz cell without further purification. Water was redistilled and further purified with a MilliQ water purification system (Millipore, USA). Standard sol-

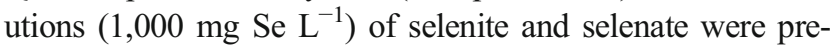
pared by dissolving appropriate amounts of sodium selenite $\left(\mathrm{Na}_{2} \mathrm{SeO}_{3}\right)$ and sodium selenate $\left(\mathrm{Na}_{2} \mathrm{SeO}_{4}\right)$, respectively, obtained from Sigma-Aldrich (USA). The standard stock solutions were stored in glass bottles at $4{ }^{\circ} \mathrm{C}$ in darkness. Low concentration standards obtained by dilution of the stock solutions were daily prepared. Sodium tetrahydroborate (III), used as reducing solution, was daily prepared, by dissolving $\mathrm{NaBH}_{4}$ (Merck, Germany) in high-purity water and stabilizing with $1 \%(w / w) \mathrm{NaOH}$ (Merck) solution to decrease its rate of decomposition. The solution was used without filtration.

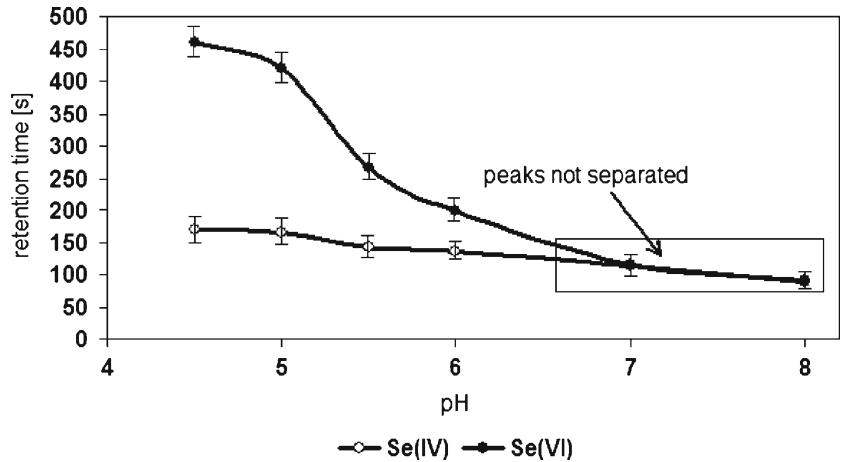

Fig. 4 Influence of mobile phase $\mathrm{pH}$ on retention time of selenium species

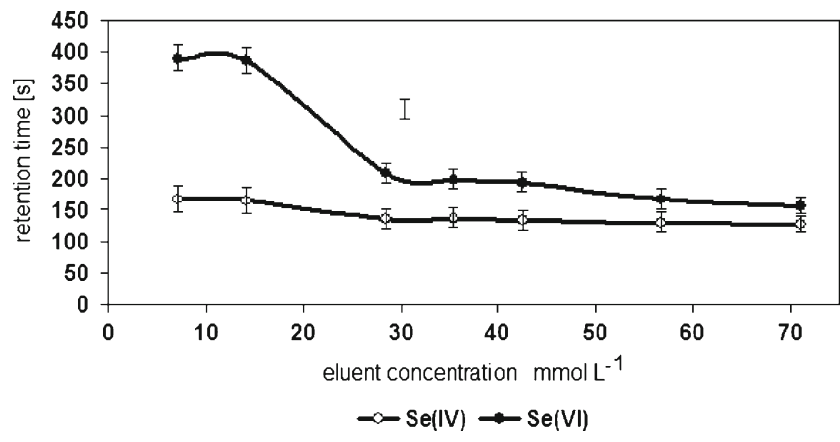

Fig. 5 Influence of mobile phase concentration (as phosphates at $\mathrm{pH}$ 5.5-6.0) on retention time of selenium species

The $\mathrm{HCl}$ solution was of the highest quality grade (Suprapure, Merck). Thiourea of analytical quality grade was obtained from Merck. The buffered mobile phase was prepared by mixing of disodium hydrophosphate $\left(\mathrm{Na}_{2} \mathrm{HPO}_{4}\right)$ and potassium dihydrophosphate $\left(\mathrm{KH}_{2} \mathrm{PO}_{4} \cdot 2 \mathrm{H}_{2} \mathrm{O}\right)$ obtained from Merck.

\section{Samples}

The dietary supplements studied are commercially available and were purchased at the chemists' shops. The study was performed for a unit dose of the preparation, e.g. for a tablet. Tablets of each preparation were weighted. Solutions for extraction of selenium compounds were chosen so that they would imitate the conditions in the alimentary system. The stage of dissolving in the stomach was reproduced with the use of hydrochloric acid, while the conditions of absorption in the intestines were reproduced with the use of phosphate buffer. One tablet of each preparation was dissolved in $25 \mathrm{~mL}$ of $\mathrm{HCl}$ with a concentration of $100 \mathrm{mmol} \mathrm{L}^{-1}$, while another 1 in $25 \mathrm{~mL}$ of phosphate buffer solution of $\mathrm{pH} 6.0$, containing $10 \mathrm{mmol} \mathrm{L}^{-1}$ of $\mathrm{Na}_{2} \mathrm{HPO}_{4}$ and $45 \mathrm{mmol} \mathrm{L}^{-1}$ of $\mathrm{KH}_{2} \mathrm{PO}_{4}$. The tablets were dissolved at $37{ }^{\circ} \mathrm{C}$. For each preparation, the extraction was three times repeated. The extracts were analysed in the HPLC-HG-AAS system,

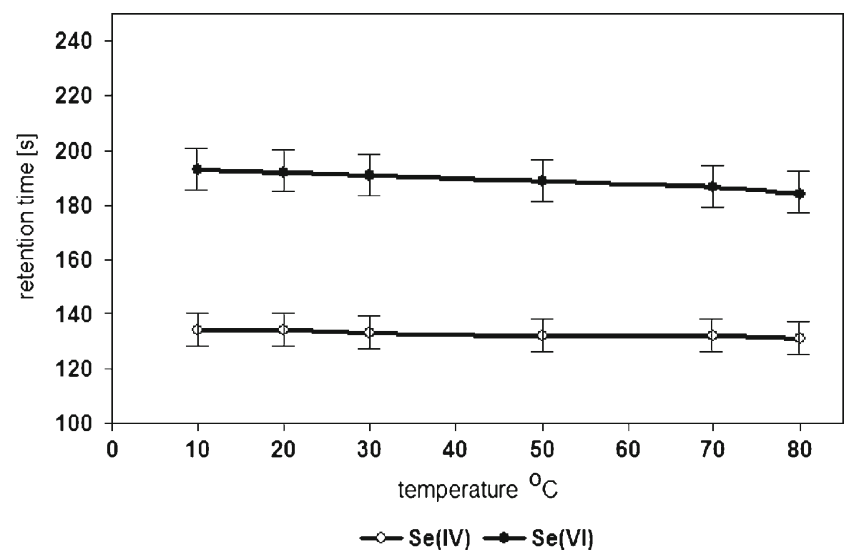

Fig. 6 Influence of separation column temperature on retention time of selenium species 


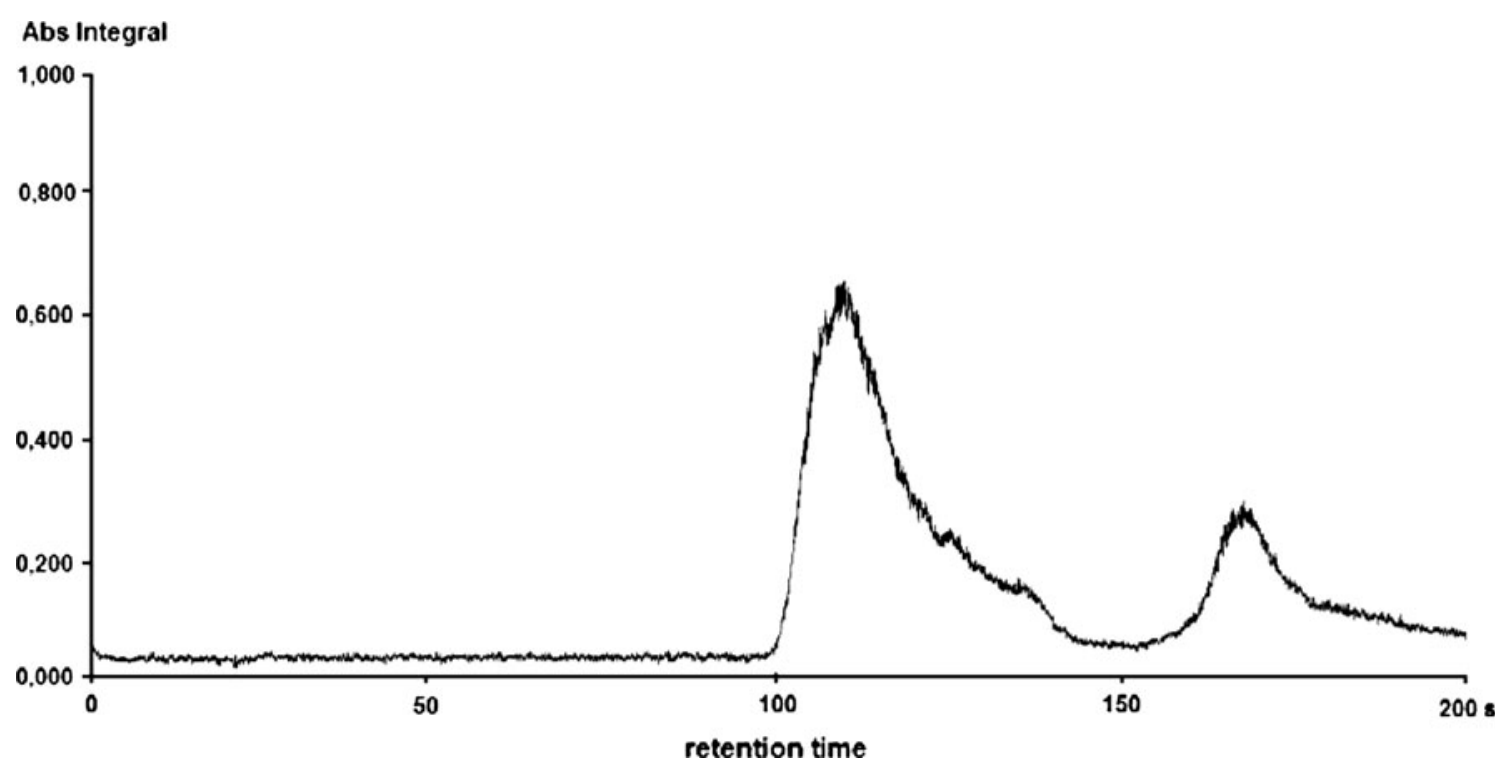

Fig. 7 Typical chromatogram demonstrating the separation of inorganic selenium species: first peak Se(IV) and second peak Se(VI)

during the short time after extraction. The forms of selenium concentration in the extracts were stable for 1-2 days, the long-time stability studies have been not performed.

The hydrochloric acid extracts were subjected to mineralisation with nitric acid. A portion of $5 \mathrm{~mL}$ of the extract was supplemented with $15 \mathrm{~mL}$ of nitric acid and the mixture was heated under reflux up to about $90{ }^{\circ} \mathrm{C}$ for $2 \mathrm{~h}$. Similar procedures of mineralisation were performed for the tablets of the preparations. One tablet of each preparation was dissolved in $20 \mathrm{~mL}$ of nitric acid heating up the mixture to about $90{ }^{\circ} \mathrm{C}$ for $2 \mathrm{~h}$. The mixtures were filtered off and the filtrate was subjected to determination of the total content of selenium using the HG-AAS method.

\section{Results and Discussion}

Optimisation of the Hyphenated Analytical System

\section{Preliminary Reduction}

Selenium species $\mathrm{Se}(\mathrm{VI})$ does not form volatile hydride, so in order to get an analytical signal in the HG-AAS system, it was necessary to perform preliminary reduction of $\mathrm{Se}(\mathrm{VI})$ to
$\mathrm{Se}(\mathrm{IV})$. The reduction was carried out on-line by heating the sample with the reducing agent. The eluate from the chromatographic column was joined with the stream of the reducing agent (flow rate $1 \mathrm{~mL} \mathrm{~min}{ }^{-1}$ from the peristaltic pump) through a T-shape coupling and directed to the polyethylene capillary loop (inner diameter $0.82 \mathrm{~mm}$ ) heated on a water bath. The capillary loop outlet was connected to the hydride generation system. In preliminary measurements, hydrochloric acid was used as a reducing agent, what had been applied by the other authors (Wallschlaeger and Bloom 2001; Bermejo et al. 2001); however no analytical signal of Se (VI) was obtained. Only the addition of thiourea to $10 \mathrm{~mol} \mathrm{~L}^{-1}$ of hydrochloric acid permitted successful reduction of $\mathrm{Se}(\mathrm{VI})$ to Se(IV). The analytical signal, measured as the area under the peak, increased for the thiourea concentration up to $0.5 \mathrm{~mol} \mathrm{~L}^{-1}$; but for higher thiourea concentrations, the signal assigned to $\mathrm{Se}(\mathrm{VI})$ species decreased, see Fig. 2.

The next objective was to establish the temperature dependence of the reduction process, in the range of $20-100{ }^{\circ} \mathrm{C}$. An increase in the yield of $\mathrm{Se}(\mathrm{VI})$ reduction with increasing temperature was observed (Fig. 3), although it was accompanied by a decrease in the analytical signal assigned to Se(IV) most probably caused by reduction of selenium to elemental form.

Table 2 Characteristic of analytical method $(n=6)$

\begin{tabular}{|c|c|c|c|c|c|c|c|}
\hline Selenium form & $\begin{array}{l}\text { Retention } \\
\text { time }(\mathrm{s})\end{array}$ & $\begin{array}{l}\text { Linearity } \\
\left(\text { ng } \mathrm{mL}^{-1}\right)\end{array}$ & Slope & $\begin{array}{l}\text { Correlation } \\
\text { ceoficient }\end{array}$ & $\begin{array}{l}\text { Detection } \\
\text { limit }\left(\mathrm{ng} \mathrm{mL} L^{-1}\right)\end{array}$ & $\begin{array}{l}\text { Max RSD } \\
100 \mathrm{ng} \mathrm{mL}^{-1}(\%)\end{array}$ & $\begin{array}{l}\text { Recovery } \\
100 \mathrm{ng} \mathrm{mL}^{-1}(\%)\end{array}$ \\
\hline $\mathrm{Se}(\mathrm{IV})$ & $109.5 \pm 1.8$ & DL-1000 & 0.0076 & 0.9904 & 10 & 10.2 & $96.4 \pm 3.9$ \\
\hline $\mathrm{Se}(\mathrm{VI})$ & $166.9 \pm 2.6$ & DL-1000 & 0.0016 & 0.9960 & 10 & 10.5 & $95.3 \pm 4.4$ \\
\hline
\end{tabular}

$D L$ detection limit 
Table 3 Results of selenium species determination in dietary supplements

\begin{tabular}{|c|c|c|c|c|c|c|}
\hline & \multicolumn{6}{|c|}{ Dietary supplements } \\
\hline & 1 & 2 & 3 & 4 & 5 & 6 \\
\hline \multicolumn{7}{|l|}{$\mathrm{Se}(\mathrm{IV})$} \\
\hline \multicolumn{7}{|l|}{$\mu \mathrm{g} / \mathrm{L}$ in solution } \\
\hline Buffer extraction & $<10$ & 13.5 & 276 & 72 & $<10$ & 229 \\
\hline Acid extraction & $<10$ & 11.0 & 183 & $<10$ & $<10$ & 212 \\
\hline $\operatorname{Max} \operatorname{RSD} \%(n=3)$ & $\mathrm{x}$ & 15 & 5 & 5 & $\mathrm{x}$ & 5 \\
\hline \multicolumn{7}{|l|}{$\mu \mathrm{g}$ in tablet } \\
\hline Buffer extraction & $<0.2$ & 0.3 & 6.9 & 1.79 & $<0.2$ & 5.7 \\
\hline Acid extraction & $<0.2$ & 0.3 & 4.6 & $<0.2$ & $<0.2$ & 5.3 \\
\hline $\operatorname{Max} \operatorname{RSD} \%(n=3)$ & $\mathrm{x}$ & 15 & 5 & 5 & $\mathrm{x}$ & 5 \\
\hline \multicolumn{7}{|l|}{$\mathrm{Se}(\mathrm{VI})$} \\
\hline \multicolumn{7}{|l|}{$\mu \mathrm{g} / \mathrm{L}$ in solution } \\
\hline Buffer extraction & $<10$ & $<10$ & $<10$ & $<10$ & $<10$ & 365 \\
\hline Acid extraction & $<10$ & $<10$ & $<10$ & $<10$ & $<10$ & 194 \\
\hline $\operatorname{Max} \operatorname{RSD} \%(n=3)$ & $\mathrm{x}$ & $\mathrm{X}$ & $\mathrm{x}$ & $X$ & $\mathrm{x}$ & 15 \\
\hline \multicolumn{7}{|l|}{$\mu \mathrm{g}$ in tablet } \\
\hline Buffer extraction & $<0.2$ & $<0.2$ & $<0.2$ & $<0.2$ & $<0.2$ & 9.1 \\
\hline Acid extraction & $<0.2$ & $<0.2$ & $<0.2$ & $<0.2$ & $<0.2$ & 4.8 \\
\hline $\operatorname{Max} \operatorname{RSD} \%(n=3)$ & $\mathrm{x}$ & $\mathrm{X}$ & $\mathrm{x}$ & $X$ & $\mathrm{x}$ & 10 \\
\hline
\end{tabular}

\section{Separation of Selenium Species}

The next stage of the study was optimisation of the conditions of chromatographic separation of selenium species, including the concentration and $\mathrm{pH}$ of the eluent (phosphate buffer). By changing the ratio of disodium hydrophosphate to potassium dihydrophosphate in the buffer, $\mathrm{pH}$ values were varied in the range (4.5-7.0) at the buffer concentration (measured as the concentration of phosphates) of 15$20 \mathrm{mmol} \mathrm{L}^{-1}$. The limited range of $\mathrm{pH}$ changes followed from the fact that it was impossible to ensure a constant concentration of the buffer at $\mathrm{pH}$ higher than $\sim 7$ or lower than $\sim 4.5$, which would imply the necessity of taking into account the changes in buffer concentration on the chromatographic separation. In the $\mathrm{pH}$ range from 4.5 to 7.0 , the retention time of Se(IV) species varied from 170 to $100 \mathrm{~s}$ (Fig. 4), but the effect of $\mathrm{pH}$ changes in the above range on the retention time of $\mathrm{Se}(\mathrm{VI})$ species was much more pronounced, it varied from 460 to $100 \mathrm{~s}$.

A similar study was performed for the eluent concentration (expressed as a content of phosphates). The range of its variation was $10-60 \mathrm{mmol} \mathrm{L}^{-1}$, while $\mathrm{pH}$ was maintained in the range 5.5-6.0 and the concentration ratio of disodium hydrophosphate to potassium dihydrophosphate as 1:10. For $\mathrm{Se}(\mathrm{IV})$, small changes in the retention time were observed in the range 170-120 s; while for $\mathrm{Se}(\mathrm{VI})$ with increasing concentration of the eluent, the retention time decreased from 390 to $155 \mathrm{~s}$ (Fig. 5).

No significant changes in the retention time of both selenium species were observed no changing the temperature of the chromatographic column from $10{ }^{\circ} \mathrm{C}$ to $80{ }^{\circ} \mathrm{C}$ (Fig. 6). With regard to this fact, further chromatographic separations were performed for the column temperature stabilised at $20^{\circ} \mathrm{C}$.

Further analytical works were conducted in the conditions specified in Table 1, ensuring well separation of the peaks assigned to $\mathrm{Se}(\mathrm{IV})$ and $\mathrm{Se}(\mathrm{VI})$ species, in a relatively short time of analysis not exceeding $200 \mathrm{~s}$ for determinations in environmental samples (Fig. 7).

\section{Characterisation of the Analytical Method}

The content of selenium was proportional to the area under the peak and to the peak height, which were measured in each experiment. However, because of the asymmetry and variation in the peak shape (dispersion) in practice only the area under the peak was taken into account. A number of validation parameters characterising the analytical method were determined (Table 2). The limits of detection and the scatter of results (measured as RSD) are comparable with those reported by other authors also when using other systems of sample separation (column-eluent; Guerin et al. 1999). As it was impossible to estimate the measurement traceability because of the lack of any certified reference
Table 4 Comparison of determined total selenium with manufacturer declaration

\begin{tabular}{lccccc}
\hline $\begin{array}{l}\text { Dietary } \\
\text { supplements }\end{array}$ & \multicolumn{2}{l}{$\mathrm{Se}(\mathrm{IV})+\mathrm{Se}(\mathrm{VI})$} & & \multicolumn{2}{l}{ Total selenium } \\
\cline { 2 - 3 } \cline { 5 - 6 } & Buffer extraction $(\mu \mathrm{g} /$ tablet$)$ & Acid extraction & & Mineralisation & Declaration \\
\hline 1 & $<0.2$ & $<0.2$ & & $18 \pm 2$ & 30 \\
2 & $0.3 \pm 0.1$ & $0.3 \pm 0.1$ & & $43 \pm 5$ & 50 \\
3 & $6.9 \pm 1.0$ & $4.6 \pm 0.8$ & & $26 \pm 4$ & - \\
4 & $1.8 \pm 0.2$ & $<0.2$ & & $28 \pm 4$ & 40 \\
5 & $<0.2$ & $<0.2$ & & $89 \pm 10$ & 10 \\
6 & $14.8 \pm 1.5$ & $10.2 \pm 1.1$ & & $27 \pm 4$ & 25 \\
\hline
\end{tabular}


materials for determination of inorganic selenium species, the recovery of each selenium species was measured upon addition of a standard to the environmental sample. The recovery of each species (Table 2) was sufficient so the analytical method HPLC-HG-AAS is suitable for determination of inorganic species of selenium: Se(IV) and $\mathrm{Se}(\mathrm{VI})$.

\section{Analysis of Dietary Supplements}

Results of determinations of the inorganic species of selenium in dietary supplement samples are presented in Table 3. In samples $1-5$, no $\mathrm{Se}(\mathrm{VI})$ species was found; while in sample 6 , this species was present in a greater amount than $\mathrm{Se}(\mathrm{IV})$ and the contribution of the former was over $60 \%$ of total inorganic selenium. The inorganic compounds were easier released from the dietary supplement samples studied to phosphate buffer. The results of determinations of inorganic selenium species and total content of selenium in the dietary supplement products are given in Table 4 together with the contents declared by the producers.

In all dietary supplement products, selenium was present mainly in the form of organic species (Amoako et al. 2009; Alzate et al. 2007; Infante et al. 2005; Dumont et al. 2005). In two samples (samples 1 and 5), no inorganic selenium species were detected. In the other samples, the inorganic selenium species made from nearly $1 \%$ to over $50 \%$ (sample 6 ) of the total content of selenium. The total content of selenium was close to that declared by the producer (in declaration has been no information about selenium forms in supplements), except for sample 5 in which the content of selenium was about 9 times greater than the declared amount.

\section{Conclusion}

Determination of the content of selenium, and in particular, the contents of its species in the food products or dietary supplements has gained importance in view of the fact of increasing appearance of selenium-enriched products on the market. Although organic selenium species are dominant in selenium-enriched products, in the dietary supplement products studied, the inorganic selenium species were also found, mainly Se(IV) but in one sample also Se(VI). The results obtained for only a few preparations indicate that caution must be exercised in their use. The hyphenated system used for the analytical studies HPLC-HG-AAS was proved to permit determination of inorganic selenium species in samples of different types. This hyphenated method is much cheaper and easier in exploitation than the commonly used for this purpose HPLC-ICP-MS and may deserve attention among those working in analytical chemistry.

Acknowledgements We would like to thank Ryszard Gasiorowski M.Sc. for helping in the laboratory work during his master thesis preparation.

Open Access This article is distributed under the terms of the Creative Commons Attribution Noncommercial License which permits any noncommercial use, distribution, and reproduction in any medium, provided the original author(s) and source are credited.

\section{References}

Institute of Medicine (1997) Dietary reference intakes for calcium, phosphorus, magnesium, vitamin D, and fluoride. National Academy Press: Washington, DC

Thomson CD (2004) Assessment of requirements for selenium and adequacy of selenium status: a review. Eur J Clin Nutr 58:391

Wolters M, Hermann S, Golf S, Katz N, Hahn A (2006) Selenium and antioxidant vitamin status of elderly German women. Eur J Clin Nutr 60:85

Davis PA, McDowell LR, Wilkinson NS, Buergelt CD, Van Alstyne R, Weldon RN, Marshall TT (2005) Effects of selenium levels in ewe diets on selenium in milk and the plasma and tissue selenium concentrations of lambs. Small Rumin Res 65:14

Guerin T, Astruc A, Astruc M (1999) Speciation of arsenic and selenium compounds by HPLC hyphenated to specific detectors: a review of the main separation techniques. Talanta 50:1

Hill SJ, Arowolo TA, Butler OT, Cook JM, Cresser MS, Harrington C, Miles DL (2003) Atomic spectrometry update. Environmental analysis. J Anal At Spectrom 18:170

Pedersen GA, Larsen EH (1997) Speciation of four selenium compounds using high performance liquid chromatography with on-line detection by inductively coupled plasma mass spectrometry or flame atomic absorption spectrometry. Fresenius J Anal Chem 358:591

Łobiński R, Szpunar J (1999) Biochemical speciation analysis by hyphenated techniques. Anal Chim Acta 400:321

Wallschlaeger D, Bloom NS (2001) Determination of selenite, selenate and selenocyanate in waters by ion chromatography-hydride generation-atomic fluorescence spectrometry (IC-HG-AFS). J Anal At Spectrom 16:1322

Bermejo P, Barciela J, Pena EM, Bermejo A, Fraga JM, Cocho JA (2001) Determination of selenium in infant formulas whey fractions by SEC HPLC HG ETAAS. J Anal At Spectrom 16:188

Marchante-Gayón JM, González JM, Fernández ML, Blanco E, Sanz-Medel A (1996) Selenium speciation by coupling vesicle mediated HPLC with off-line ETAAS and on-line focused microwave digestion HG-AAS detection. Fresenius J Anal Chem 355:615

Niedzielski P (2005) The new concept of hyphenated analytical system: simultaneous determination of inorganic arsenic (III), arsenic (V), selenium (IV) and selenium (VI) by high performance liquid chromatography-hydride generation-(fast sequential) atomic absorption spectrometry during single analysis. Anal Chim Acta $551: 199$ 
Amoako PO, Uden PC, Tyson JF (2009) Speciation of selenium dietary supplements; formation of S-(methylseleno) cysteine and other selenium compounds. Anal Chim Acta 652:315

Alzate A, Cañas B, Pérez-Munguía S, Hernández-Mendoza H, PérezConde C, Gutiérrez AM, Cámara C (2007) Evaluation of the inorganic selenium biotransformation in selenium-enriched yogurt by HPLC-ICP-MS. J Agric Food Chem 55:9776
Infante HG, Hearn R, Catterick T (2005) Current mass spectrometry strategies for selenium speciation in dietary sources of highselenium. Anal Bioanal Chem 382:957

Dumont E, De Cremer K, Van Hulle M, Chéry CC, Vanhaecke F, Cornelis R (2005) Identification of the major selenium compound, Se-Methionine, in three yeast (Saccharomyces cerevisiae) dietary supplements by on-line narrow bore liquid chromatographyelectrospray tandem mass spectrometry. J Chromatogr A 1071:191 